\title{
下雅助に発生した助触脈奇形
}

\author{
石踊利文・福田庭志・染谷さ子・田所盾映
}

\section{Arteriovenous malformation of the mandible}

\author{
Toshihumi Ishibashi - Hiroshi Fuxuda - Sakiko Someya - Shigeaki Tadokoro
}

\begin{abstract}
Arteriovenous malformations of the jaws are considered to be rare lesions, A-14-yearold school boy was referred from a hospital for profuse bleeding after the extraction of the mandibular right first molar. Orthopantomography showed an irregular radiolucency extending from the mandibular right lateral incisor region to the right mandibular notch and dental film showed "soap bubble" appearance. In angiogram the main feeding vessels appeared to be the right facial artery, the right lingual artery, the right inferior alveolar artery, the right massteric artery and the right buccal artery. Expecially the right facial artery was as enlarged as the right external carotid artery. Embolization of the facial artery was performed to decrease the blood flow in the region of the mandibular lesion. The next day under nasoendtracheal general anesthesia, preparations were made for enucleation by the ligations of the right external carotid, right lingual and right facial arteries. The enucleation of the tumor was carried out by an intraoral approach. The beginning of the operation was followed by profuse bleeding. However, after the ligation of the right inferior alveolar artery, hemorrhage was controlled and the tumor was removed with relative ease. The postoperative course was entirely without complications. Anorthopantomography taken one year and seven months after the operation showed significant osseous regeneration in the area of the lesion. The pathological diagnosis was arteriovenous malformation.
\end{abstract}

Key words: arteriovenous maloration, mandible

緒 曹

顎の血管異常は通常，領骨血管腫，頻骨中心性血管嗹， 海綿状血管腫として報告されているが1ー4)，頻の動静脈 奇形 ${ }^{(5)}$ ，顎の血管奇形 ${ }^{(6)}$ ，搏動性血管腫 ${ }^{7}$ 等としての報 告もみられる。このような䪽の血管の䂏患はかなりまれ な疾患で，場合によっては死の転帰をとる疾患として報 告されている,

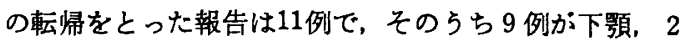
例が上顎であり，死の主な原因は 9 例が拔歯による出血 死で, 術前の出血による窒息死, 生饸による出血死が各

筑波大学臨床医学系口腔科

（主任：根本一男教授）

Department of Stomatology, Institute of Clinical Medicine, University of Tsukuba (Chief: Prof. Kazuo Nemoto)

受付日：昭和59年 3 月 5 日
1 例だったと述べている。一般的にこの㗨患が隔床的に

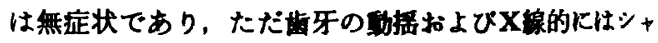
ボン玉型の陰影像を示しているにすぎず，抜歯または組 織生梭の時の異常出血として発見されると報告されてい $3^{1-4)}$

最近，著者らは某齿科飞て可拔齿後異常大量出血

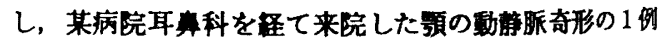
を経検したので，その概要を報告するとともに，從来の 報告例について検索したので報告する。

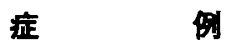

患 者: 14葴 男性.

初 診：1982年 3 月 .

主 訴: $\overline{6}$ 拔齿後の異常大量出血.

家族歴およひ垦往歷：特記すべき事項なし. 現病歴：5藏頃から食事の時，時に右下影乳日歯歯肉 より出血した時あり．1982年 2 月初旬，可が動摇し痛 


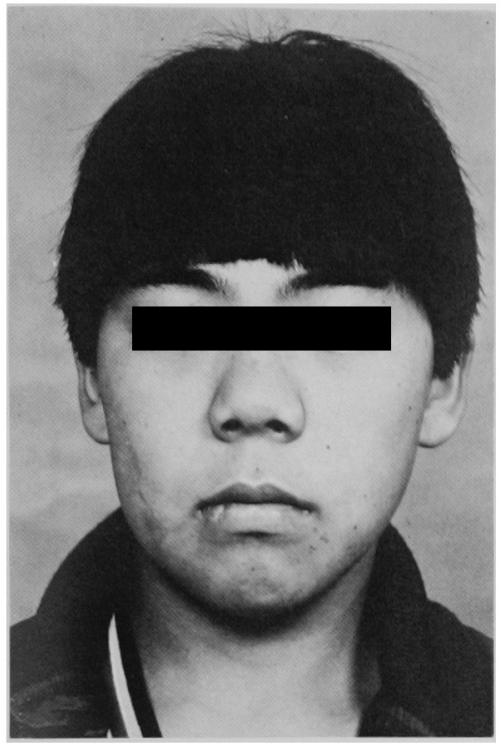

写吉 1 初診時顔琓

み出し、某棶科受診し 1 か月程通院治療をしていたか， 動摇が強くなったため 3 月日日可|を拔幽された。可|抜 去後瞬時に血が噴き出し, 脱脂綿, 徒手にて压迫止血さ れた。 ただらに某病院耳鼻科に入院し，止血処固として 脱脂綿によるタンポナーデが施され，齿肉に释合固定さ れ，止血剤の全身投与を受けた。 その時の出血量は的 $1,000 \mathrm{ml}$ で， $800 \mathrm{ml}$ 輸血されていた，3月日当病院 を紹介され即日入院した。

現症：口腔外所見；体格強健，栄養状態良好たったが， 顔色は荅白であった，右頓部はび漫性に尰脹しており， 右顎下リンパ節は小指頭大に尰脹し，可動性で圧痛を認 めた（写真 1 ).

口腔内所見; 開口障害あり（開口域 2 横指） $\overline{6}$ !の抜 歯創は脱脂綿によりタンポナーデされており，歯肉の腫 脹, 発赤, 压痛を認めたが出血はなかった（写真 2). $\overline{5} \mid$ および $\overline{7} \mid$ は歯牙の動摇が強く、いわゆる舞踏様の動 採を呈していた。他の歯牙は智雪が末萌出で原にアマ ルガム充買を認めるのみで健全であった，その他口腔粘 膜に異常を認めなかった。

X線所見：オルソパントモおよび下靧骨斜位撮影法で は $\overline{2} \mid$ より右下矤枝関節突起基部まで, 境界不明瞭な透 過像を認め，骨梁は消失，骨の吸収を疑わせる像を認め た（写直 3，4）. 頭部 P-A 像では煩側への膨隆像を， 口内撮影法では $\overline{5}|\overline{7}|$ の部で，歯根膜腔，歯槽硬線の 消失およびシャボン玉状の陰影欠損を認めた（写真 5).

初診時臨床検查所見；CRP（土）のほか特別異常值は 琵められなかった。

臨床診断：下㖽骨中心性血管腫.

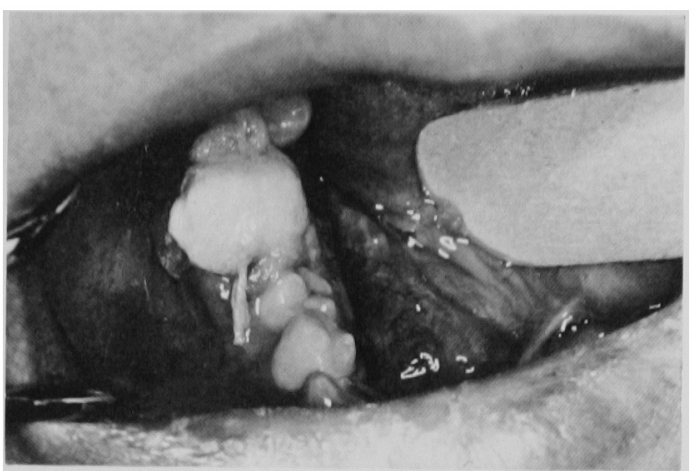

军竞 2 初殸時口腔内の状態 网口障望杖よび $\overline{6} \mid$ 部に脱脂綿がタンボナーデされ ている。

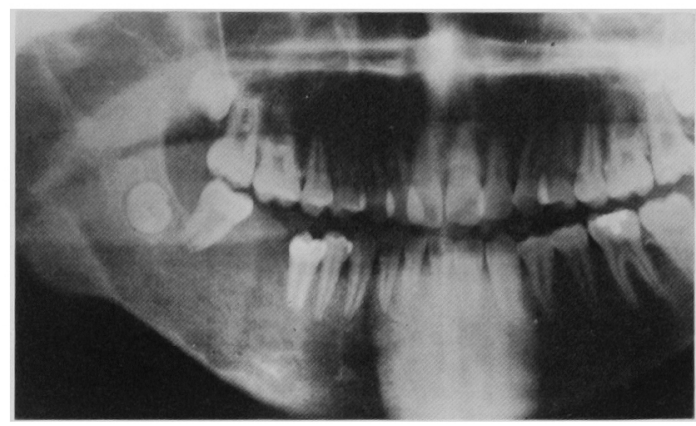

写直 3 初診時のオルンパントモ像

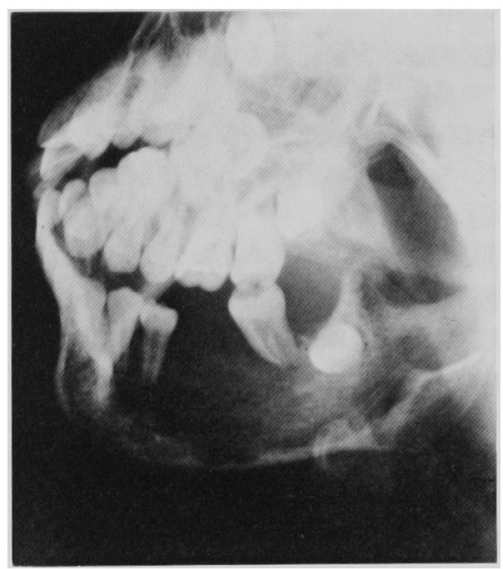

写直 4 初診時下顥骨拣位投影法X線像

処置および経過：入院当初出血による全身衰弱に対し

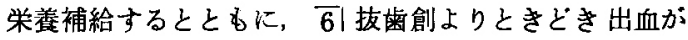
認められたため，出血防止のためにレジン床副子を 765 部に装着した。病巣部への栄養血管確認のため血 管造影を当院放射線科に依頼した，血管撮影では顎骨病 


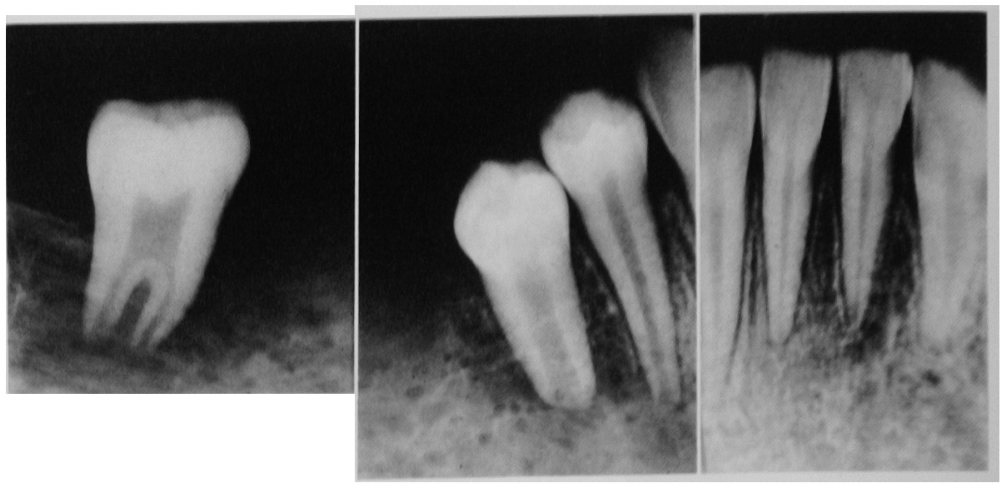

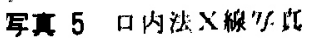

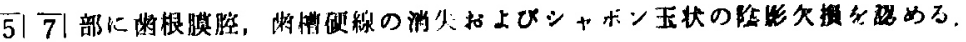

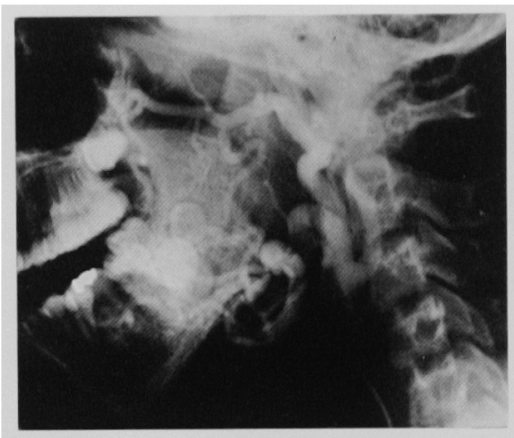

写真 6 血管掫影

顔面動脈の拡㖘が㒛められる。

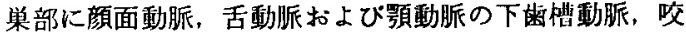
筋動脈，頓動哌より输入しているのが認められ，とくに 顔面動脈は外頸動脈本幹とほほ同程度に払張して顎骨に 進入しているのが琶められた（写真 6)．そこで，顔面 動脈の人工塞栓術を施行後，患者の希望むあり，ます䫫 骨を保存して摘出手術をすることとし，場合によっては 右下顎半側切除をする方針とした，顔面動脈の人工塞栓 術は当病院放射線科にて施行された. Gelfoam 小片（1 $\times 1 \times 2 \mathrm{~mm}$ 程度) 60 個を使用して行ったが, 顔面動脈が 払張しているため，十分な効果は得られなかったといら 報告であった，翌日の3月目経鼻挿管全麻下にて摘出 術を行った。はじめに右総顥動脈を露出させ，外顒動 脈，舌動脈，顔面動脈を確認し，外澒動脈起始部，舌動 脈，顔面動脈の順に結禁した，次に口腔内より $\overline{754} \mid$ の 拔霜後，粘膜を切開剝雑して摘出を始めた，摘出開始時 外頸動脈，舌動脈，顔面動脈を結禁したにもかかわらず 出血が多くガーゼにて圧迫止血して，しばしば手術を中 断せざるを得なかった。そこで額動脈からの輸入動脈の 下歯慒動脈結禁してから手術を進めることとし，下罘小 舌部で下歯槽動脈を結禁した，結禁後は出血は激減し㔀

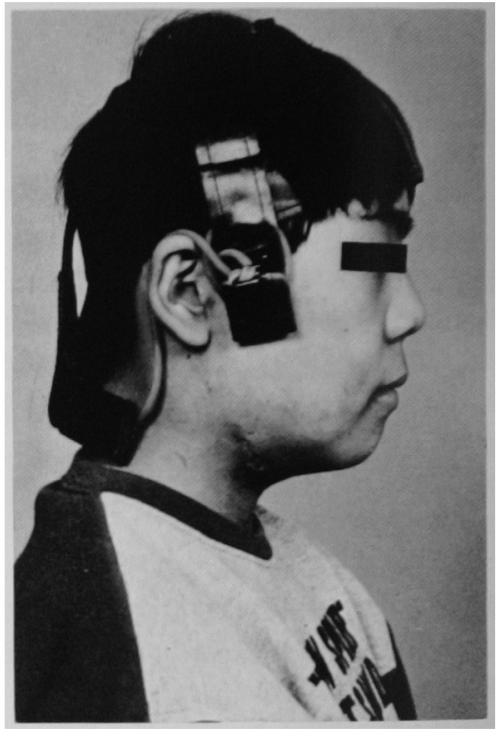

军真 7 退院時の勆貌

離摘出は比較的容易になり，摘出に従い出血は他の一段

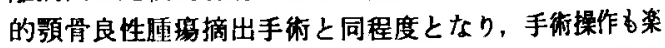
になり，完全に别離摘出することができた。なお頻骨病 栄内には，来院前の止血処置の時に㧌入されたと思われ る悪息の強い脱脂綿 1 枚を発見し摘出した．摘出後は工 アトームで骨整形, bone wax, oxyzel を括入して止血 し，口腔粘膜をデキンン系にて椎合し，術前装着してお いた三内式シーネを，術後骨折予防のため、もムにて額 間固定した。頸部は通法に従い擗合して手術を終了し た。本手術の総出血量は $3,500 \mathrm{ml}$, 輸血量は $3,000 \mathrm{ml}$, 輸液量は $3,400 \mathrm{ml}$ 手術時間は 4 時間20分であった。

術後の創の治㴔释過は順調で，顥間固定を14日間行い 释過観察していたが，䫑に過度の打揧が加からなければ 骨折はないと判断し， chin cap の類外固定に变更し17 


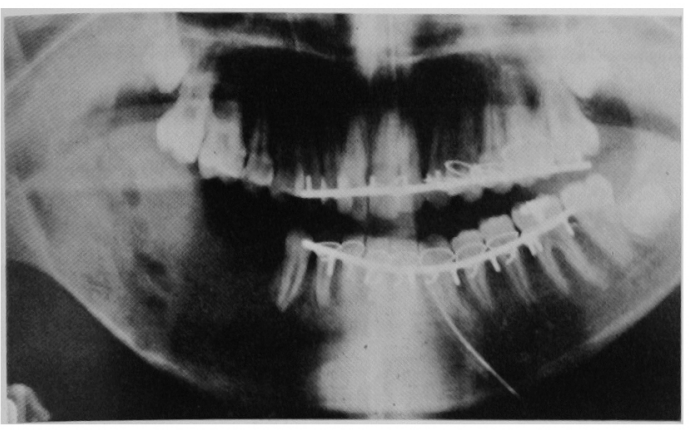

写真 8 手原後のナルンパントモ像

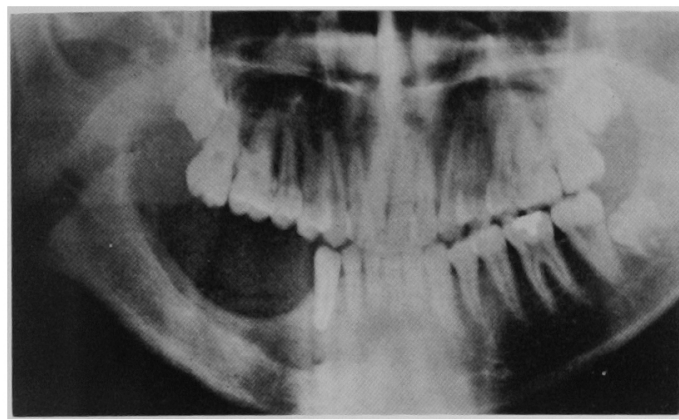

军真 9 街後 1 年 7 か月後のオルンハントモ像

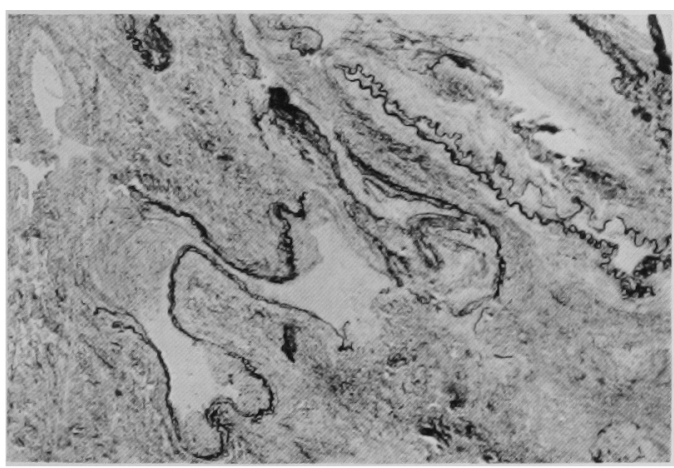

写真 10 Von Gieson 染色

日目に退院した（写真 7 ）。術後 1 年 7 か月現在, 術值 後からの右下唇オトガイ部の知覚麻痺も消失し，再発も なく久損部には義歯も装着され元気に通学している，写 直 8 は手術直後のオンソパントモ像であり，写直 9 は 1 年7か月後のもので骨梁も明瞙で, 骨の再生, 增生が認 められる。

病理組和学的所見および病理組馀断：異物に対する 反応が強く認められ肉芽腫様所見を呈しており，血管腫 といら所見が認められないといらことで，摘出標本の block 連続切片を作製した，標本では，脱脂綿の 1 部と

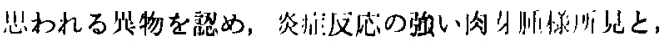

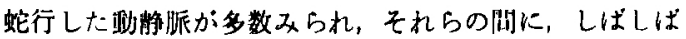

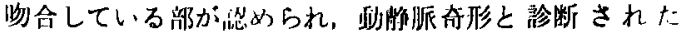
(军索10).

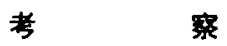

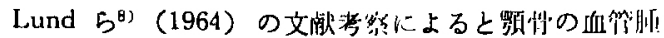
について收初に登泶したのは Stanley（1849）であり。

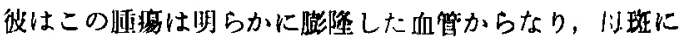

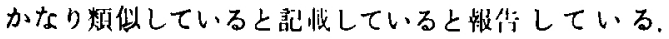
Hitzrot ${ }^{10)}$ (1916) は，收初に上㰾骨に発生した悄の血

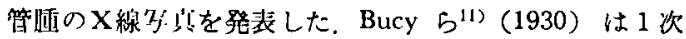
性の骨血管腫 8 例の韩台と文献例についての㭘索で，骨

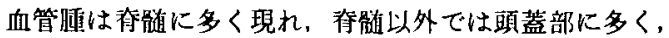
顎骨に発現したのは下颚 2 例，硬口盐 2 例，上䫈 1 例 計 5 例であったと述べている. Geschickter ら ${ }^{12)}$ (1938) はBucy ら後の骨血管肺について検索したところ49 例 あり，そのらち額骨に発現したのは 5 例であったと述べ ている. Watson ら ${ }^{13)}(1940)$ は血管リンハ管恠瘍 1,056 例中，骨に発現した血管嗹は 5 例であり，そのうち頻骨 に生じたものは1例であったと報告している，Smith4 (1959) は Stanley（1849）からの鿓骨の血管嗹の䟥告

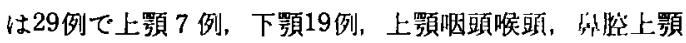
頭蓋底，上顎下顎各 1 例であり，てのうち抜战による出 血死亡例は 3 例だったと述べている，Lund ら (1964) は文献例35例のうち Mayo clinic での自験例 4 例を加 え，年制の不詳なむの1例を除いた38例について娭索 し，顎骨の血管尰は10歳代に多く出現し，死亡例 3 例も 10歳代に恋められ，男女比は1：2であったと報告して いる. Dahlin ${ }^{14)}$ (1978) によれば，1975年までの Mayo clinic での骨腫瘍 6,221 例中骨血管腫は69 例（1.1\%） であり，そのらち額骨に生じたものは11例たったと述べ

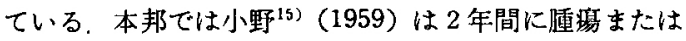
要胞を疑わしめたもの 244 例中，顎骨中心性の血管腫は

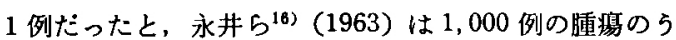
ち，䫟骨に生じた血管腫は３例であったと述へている。

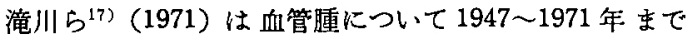
の 24 年間の口腔外科領域の文献的集計を行い, 自験例 および文献例179例中顎骨内に生じた血管腫は10例（5.6 \%)であったと述べている，佐竹ら ${ }^{18)}$ は過去10年間の血 管腫115例中，澦骨内に生じたものは 2 例 (1.7\%) であ ったと，橋本ら ${ }^{19)}$ (1977) は10年間の血管尰 127 例中顎 骨内の血管腫は 1 例であったと報告している．著者らも 本例以外に現在柽塞法にて治療し, 経過観察中の 1 例を 経験しているが，いずれにしても顎骨中心性血管腫はま れな疾患と思われる。

1933年までの筫血管腫（動静脈奇形も含む）としての 本邦の症例報告は著者らの涉猟したもので 31 例 ${ }^{16 ~ 18,20 ~}$ 
表 1 本邦に打ける顎の血管腫（動静脈奇形を含む）の報告例（1952-1984）

\begin{tabular}{|c|c|c|c|c|c|c|c|c|c|c|c|c|c|}
\hline \multirow{2}{*}{$\begin{array}{l}\text { 症 } \\
\text { 例 } \\
\text { 数 }\end{array}$} & \multirow{2}{*}{ 報告者 } & \multirow{2}{*}{$\begin{array}{l}\text { 報 } \\
\text { 告 } \\
\text { 年 }\end{array}$} & \multirow{2}{*}{ 性 } & \multirow{2}{*}{$\begin{array}{l}\text { 年顎 } \\
\text { 齢 別 }\end{array}$} & \multirow{2}{*}{\multicolumn{2}{|c|}{$\begin{array}{l}\text { 左 } \\
\text { 右 } \\
\text { 別 }\end{array}$}} & \multirow{2}{*}{ 主訴または主症状 } & \multirow{2}{*}{$\begin{array}{l}\text { 自覚 } \\
\text { 期間 }\end{array}$} & \multirow{2}{*}{ 臨床診断 } & \multicolumn{3}{|c|}{ 主な治療内容 } & \multirow{2}{*}{$\begin{array}{c}\text { 病理組織 } \\
\text { 診断名 }\end{array}$} \\
\hline & & & & & & & & & & 血管 & 結禁 & 処 & \\
\hline 1 & 松島ら & 1956 & 男 & 12 & 上 & 右 & 抜歯後出血 & {[} & 血管腫 & & & 腫瘍摘出 & \\
\hline 2 & 河 西 & 1957 & 男 & 19 & & 右 & - & - & 血管腫 & 外頸 & (他動脈 & $\begin{array}{l}\text { 抜歯, スポンゼル } \\
\text { 填塞, 放射線治療 }\end{array}$ & \\
\hline 3 & 永井ら & 1963 & 男 & 13 & 下 & 左 & 蒾牙の動摇 & 1 か月 & 血管腫 & 外頸 & 動脈 & 下顎骨切除 & 海綿状 \\
\hline 4 & 山中ら & 1963 & 女 & $21-$ & 下 & — & 下顎の腫脹 & 10年 & 血管腫 & 両側外頸 & 動脈 & 下顎骨切除 & $\begin{array}{l}\text { Fibro-Osteo- } \\
\text { H. }\end{array}$ \\
\hline 5 & 山中ら & 1964 & 女 & 26 & 上 & 右 & 無痛性骨性腫脹 & 6 か月 & $\begin{array}{l}\text { 線維性骨異 } \\
\text { 形成症 }\end{array}$ & 右外頸 & 動脈 & 上顎骨切除 & 海綿状 \\
\hline 6 & 小谷ら & 1964 & 男 & 37 . & 上 & - & 硬口蓋の腫脹 & 6 年 & 血管腫 & & & $\begin{array}{l}\text { 放射線療法（上顎 } \\
\text { 骨切除） }\end{array}$ & 海綿状，腺癌 \\
\hline 7 & 久野ら & 1965 & 女 & 4 & 下 & 右 & 歯肉の腫脹 & 6 か月 & 血管腫 & & & 放射線療法 & 海綿状 \\
\hline 8 & 藤井ら & 1966 & 女 & $13-$ & 下 & 右 & - & - & 血管腫 & 外頸 & 動脈 & 放射線療法 & - \\
\hline 9 & 中久喜ら & 1967 & 男 & $20-$ & 下 & 右 & 下唇の麻瘏 & $\longrightarrow$ & 血管腫 & 右顔面 & 動脈 & 梱包療法 & - \\
\hline 10 & 滝川ら & 1971 & 男 2 & 25 & 下 & 左 & $\begin{array}{l}\text { 口底, 舌下, 顎下部 } \\
\text { の無痛性腫脹 }\end{array}$ & 1 か月 & 血管腫 & 左外頸 & 動脈 & $\begin{array}{l}\text { 梱包療法 } \\
\text { 下堮連続切除 }\end{array}$ & 海綿状 \\
\hline 11 & 飯田ら & 1974 & 男 2 & 24 & & 右 & $\begin{array}{l}\text { 上顎, 煩の腫脹咀 } \\
\text { 嚼障害 }\end{array}$ & - & 血管腫 & & & 冷凍外科療法 & \\
\hline 12 & 中島ら & 1974 & 女 1 & $19^{-}$ & F正 & E中 & $\begin{array}{l}\text { 下ロ唇の腫脹 } \\
\mid 2+3 \text { 疼痛 }\end{array}$ & - & 血管腫 & 外頸 & 動脈 & 下顎骨連続切除 & - \\
\hline 13 & 佐竹ら & 1975 & 男5 & $54-$ & 下 & 右 & $\begin{array}{l}\text { 下顎枝の無痛性腫 } \\
\text { 脹 }\end{array}$ & 2 か月 & 血管腫 & 顔面, 後豇 & 碩, 顎動脈 & 下顎骨切除 & 海綿状 \\
\hline 14 & 河合ら & 1976 & 女 1 & $11-$ & 下 & 左 & $\begin{array}{l}\text { 下顎大曰歯の疼痛 } \\
\text { 出開口障害 }\end{array}$ & 1 年 & 血管腫 & 左外頸 & 動脈 & 下顎骨切除 & 過誤腫 \\
\hline 15 & 山田ら & 1976 & 女 1 & 19 & 下 & 右 & $\begin{array}{l}\text { 下顎大曰歯の瀮漫 } \\
\text { 性出血 }\end{array}$ & 2 年 & 血管腫 & 右外頸 & 動脈 & 縫合術 & \\
\hline 16 & 飯田ら & 1977 & 男 2 & 23 & 上 & & - & 23 年 & 血管腫 & & & 冷凍外科療法 & 毛細，海綿状 \\
\hline 17 & 飯田ら & 1977 & 男3 & 34 & 七 & & - & 数年 & 血管腫 & 右外頸 & 動脈 & 冷凍外科療法 & 海綿状 \\
\hline 18 & 飯田ら & 1977 & 女2 & 23 & 下 & 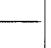 & - & 数年 & 血管腫 & 下歯槽 & 動脈 & 冷凍外科療法 & 海綿状 \\
\hline 19 & 飯田ら & 1977 & 女 4 & 48 & t & - & - & 14 年 & 血管腫 & & & 冷凍外科療法 & 海綿状 \\
\hline 20 & 古賀ら & 1979 & 男 5 & 59 & t & 左 & 鼻出血 & - & 血管腫 & 左外頸 & 動脈 & 栓塞法 & - \\
\hline 21 & 清水ら & 1979 & 男 2 & 25 & 下 & 左 & 歯肉出血 & 16年 & 血管腫 & 左外頸 & 動脈 & 下顎骨切除 & 血管腫 \\
\hline 22 & 阿部ら & 1979 & 男 2 & 26 & & 右 & $\begin{array}{l}\text { 歯肉より断続的出 } \\
\text { 血 }\end{array}$ & 20年 & 血管腫 & 右総頙 ( & 他院で） & $\begin{array}{l}\text { 抜菌, オキシセル } \\
\text { 填塞 }\end{array}$ & 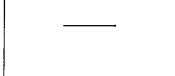 \\
\hline 23 & 松田ら & 1980 & 男 2 & $26^{-}$ & & 左 & 大臼歯無痛性腫脹 & 6 日前 & 血管腫 & 左外頸 & 動脈 & $\begin{array}{l}\text { 下顎骨切除 } \\
\text { 頸部 リンパ廊清 }\end{array}$ & 海綿状 \\
\hline 24 & 山下ら & 1980 & 男 1 & $10-$ & & 左 & 下顎の無痛性腫脹 & 7 か月 & 腫痬？ & $(-$ & -) & $\begin{array}{l}\text { 放射線療法 } \\
\text { 下顎骨切除 }\end{array}$ & 海綿状 \\
\hline 25 & 石川ら & 1981 & 男了 & 36 & & 右 & 茵牙の動摇と鈍痛 & 3 週間 & 血管腫 & 右外 & 頸動脈 & 上顎骨切除 & - \\
\hline 26 & 二瓶ら & 1981 & 女 1 & 14 & & 右 & 上顎頓部の腫脹 & - & 血管腫 & 外頸 & 動脈 & $\begin{array}{l}\text { 抜茵, オキシセル } \\
\text { 填塞, 電気焼灼 }\end{array}$ & - \\
\hline 27 & 塩入ら & 1981 & 女 & 2 & & 右 & $\begin{array}{l}\text { 舌・オトガイ下の } \\
\text { 腫脹 }\end{array}$ & 1 年半 & \begin{tabular}{|l|} 
血管腫 \\
リンパ管腫
\end{tabular} & 顔面 & 動脈 & \begin{tabular}{|l} 
栓塞法 \\
顎骨切除
\end{tabular} & $\begin{array}{l}\text { 海綿状, 血管 } \\
\text { 内皮腫, 毛細 } \\
\text { 管 }\end{array}$ \\
\hline 28 & 岩田ら & 1981 & 女 1 & $11-$ & & 左 & 歯肉の腫脹 & 1 か月 & 血管腫 & 外頸 & 動脈 & 腫瘍摘出, 搔爬 & ${ }^{\theta} \quad-$ \\
\hline 29 & 笠崎ら & 1982 & 女 1 & 16 & & 左 & 雬肉出血 & - & 動静脈奇形 & & & 栓塞法 & - \\
\hline 30 & 桜井ら & 1983 & 女 1 & 14 & & 右 & 無痛性の腫脹 & - & 血管腫 & & & 栓塞法 & 海綿状 \\
\hline 31 & 柳沢ら & 1983 & 女 5 & 55 & & 右 & 口腔内出血 & 16日前 & 動静脈瘻 & $\begin{array}{l}\text { 外頸 } \\
\text { 下顎後 }\end{array}$ & $\begin{array}{l}\text { 動脈 } \\
\text { 静脈 }\end{array}$ & 下顎骨切除 & 一 \\
\hline 32 & 著者ら & 1984 & 男 1 & 14 & & 右 & 拔歯後出血 & 9 年前 & 血管腫 & $\begin{array}{l}\text { 右外頸, 舌 } \\
\text { 下歯槽動 }\end{array}$ & 占,顔面 & $\begin{array}{l}\text { 栓塞法, 摘出 } \\
\text { 搔爬 }\end{array}$ & 動静脈奇形 \\
\hline
\end{tabular}


衰 2 性別，年路別

\begin{tabular}{c|c|c|c}
\hline 年恰 & 男 性 & 女 性 & 叶 (\%) \\
\hline $0 \sim 9$ & & 2 & $2(6.3)$ \\
$10 \sim 19$ & 5 & 8 & $13(40.6)$ \\
$20 \sim 29$ & 7 & 3 & $10(31.2)$ \\
$30 \sim 39$ & 3 & & $3(9.4)$ \\
$40 \sim 49$ & & 1 & $1(3.1)$ \\
$50 \sim 59$ & 2 & 1 & $3(9.4)$ \\
\hline 話(\%) & 17 (53.1) & $15(46.9)$ & $32(100.0)$ \\
\hline
\end{tabular}

表 3 䫚别，左右别

\begin{tabular}{|c|c|c|c|c|c|}
\hline & 左 & 正中部 & 右 & 即教なし & 計 \\
\hline 上 頻 & 2 & & 7 & 4 & $13(40.6)$ \\
\hline 下 額 & 7 & 1 & 9 & 2 & $19(59.4)$ \\
\hline 計 & 9 & 1 & 16 & 6 & $32(100.0)$ \\
\hline
\end{tabular}

44)，自験例 1 例を加六計32例であった（表 1 ），飯田ら $82 ）$ （1977）の血管腫は，Cryosurgery としての報告 35 例中 の 4 例として表に掦载され简単に記熾された以外，松島 $5^{20)}$ (1956) から自験例まですべて 1 例報告であった。 表 1 は本疾患の本邦症例報告例であるか，以上の報告例 について，性別，年龄，䪽別発現率，主訴または主症状 および自覚期間，単純X線所見，血管撮影，臨床訩断， 発生機序, 治療法, 病理組轼診断の順に検討してみた W.

性 別：骨血管腫では Dahlin'14)が女性が男性のはほ 2 倍発現していると述べている。影骨では Smith'は文 献例29例のらち性別の記載のあったのは22例で，男性10 例，女性12例であり，Lund $5^{8)}$ は38例中男性14例，女

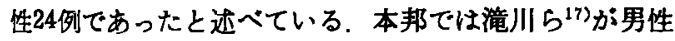
4 例，女性 5 例で明らかな性差はないと述べており，著 者らの検索でも男性17例，女性15例ではとんど差は認め られなかった（表 2).

年 龄: Dahlin ${ }^{14)}$ は骨血管腫は通常成人に詡められ, そのらちほぼ $1 / 3 か ゙ 40$ 紫代に出現していると述べてい る. 敄骨に対しては Lund ら8)は10歳代にいちぱん発現 していたと述べて和り, 石川らうは約半数が20歳以下に みられると述へててる，本疾患の本邦での来院時の年些命 は表 2 にあるよ5に，10歳代13例 (40.6\%)，20藏代 10 例 $(31.2 \%)$ に集中しており，平均年龄は23.5歳であっ た，以上のように顠骨の血管腫は欧米では10藏代に多く 発現し，本邦では10歳代，20歳代に発現している.

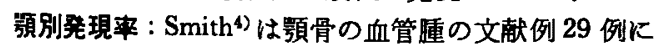
おける上下顥の比率は約 1 ：2て下類に多く発現してい たと述へている，一方， Lind 583は文献例 35 例の上下 頻の比率は1：1.5と下䫛に多く，この理由は下顥の方か
上顆より外信を受けやすいためであろらと推答してい る。著者らの梌案では上顆13例，下顆19例で，上下㖽の 比率は約1：1.5であり（衰3），Smith より Lund らの 報告と同じ値を示していた。

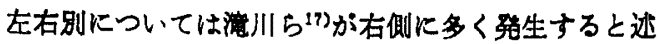
ペており，著者らの㭘索では左㑡 9 例，右側16例，正中 部 1 例，記载なし 6 例であり，左右の比戠は1:1.77で 滰川らの報告ほど極端ではないが右側に多かった。しか しながらその理由に图しては，明らかな原因を解明でき なかった。

主诉むたは主症状およひ自览期凨：本疾患は臨床的に 缚野性の青味がかった腫脹として，口腔内に出現するの

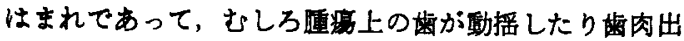
血が生じたりして発現してくるといわれている゙．本邦 では26症例に記载あり，そのうち重複は 4 例で30例につ いて佮討すると出血は 9 例, 腫脤14例, 崡牙の動播 2 例, 疼痡 2 例, 下唇の麻㽻, 開口障害, 阻嗳障害各 1 例 であった（表 1)。すなわち疼痛のない腫脹と出血異常 が二大症状であり，従来の報告と同様であった，

自覚期間の明らかな症例は22例であり，その期間は6 日間から23年までとかなりばらつきが認められたが，1 年以内は11例であり, 約半数以上は 1 年以上前から気つ いていたことが推察できる.

単純X線所見：額骨の血管腫に関して比較的特徴のあ るものは，X線所見であるといわれている4)，口腔内の 血管尰は，上䫑より下頼に特徵があるといわれ最も一般 的な型は, “honey comb”または"soap buble”とされ ている1,4)

Weinstein 5 ${ }^{46)}$ (1963) は影骨血管腫病変のX線像を （1）長く，薄い不規則な骨中隔により希薄化した小房形 成を思わせる型, (2) honey comb または soap-babble 型，（3） “sunburst effect” 型の 3 型に分類しており,こ れらの血管間に存在する骨小柱によるものと述へてい る. また, Worth 547) (1979) は (1) [Cystlike, (2) Cyst-like trabeculated, (3) Cancellous, (4) Linealy trabeculated の 4 型に分類し，さらにそれぞれを 3 型に 小分けし，計12型に分類している，本邦でのX線像の所 見を検討すると，記载のあったのは32例中22例であり， 蜂巣状 (蜂賲状, 蜂窩状) 所見 9 例, soap babble 型は 4 例，透過像と記载されたものは 5 例，焦胞状 1 例，蜂 巣状気泡状混合 1 例, 蜂巣状および sunburst effect 1 例，変化なし1例が認められた，歯根吸収のあった症例 は3 例（自験例を含む）であった。このようなX線像を 示するのは顥骨では慢性骨髄炎, 骨肉尰, 巨細胞腫, 骨 線䧽腫, 線維性骨異形成症, エナメル上皮腫, 雚胞, 骨 原粘液隀などで，その監別診断が必要とされている，慢 性骨髄炎の場合は現病歴および現症において必ず炎症の 原因と症状が怹められ，骨原肉腫とは悪性腫瘍としての 症状により爁別が可能であるが，その他疾患との艦別診 


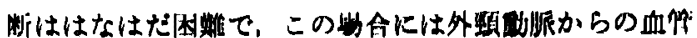

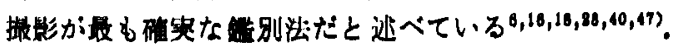

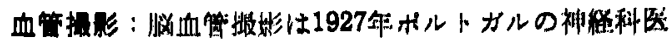

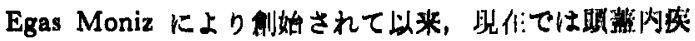

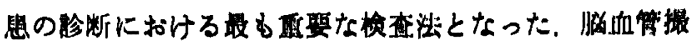

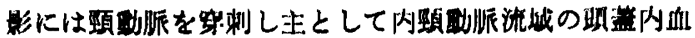

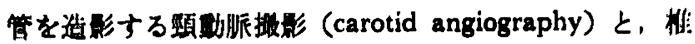

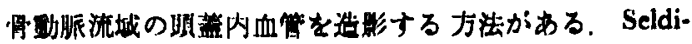
nger (1953) は経皮的㽖脈内カテーテル捅入法を考策 し，その後スエーデンの放射繼科・医らにより完成された

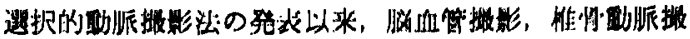
影、颙野脈脚影にカテーテル法を探用ナるものが多くな ってきた。 この方法は経皮的に北治者や示供にも利用で き，造影用の血管外注入の危隃がな，とくに術者の欲

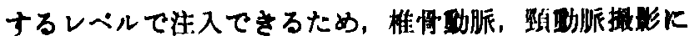
多く採用されている18,18). Hoey ら 腫の晾断に血管揋影法が最良であるとして，その血要性 を力説しており，手術前に施行された血管搬影像は，彼 らの報告例を含めた文献例で42症例中 7 例にのみ施行さ れ，さらに手術後の血管搌影像は 3 例のみであったと速 べている，本邦において血管撮影像を施行した症例は， 佐竹らから認められ以後自検例を含め13例（約 $41 \%$ ）に 認められ，かなり診断上重要な検査法になっている.

臨休診断：䫟血管尰がまれな疾患なためかなり政别診 断が難しいといらことは前述したとおりである。初診時

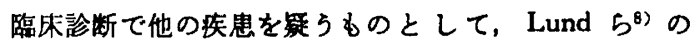
ameloblastoma, dentigerous cyst, choukas $5^{48)}$ (1963) の Cystic mass 等の報告があり，本邦では，山中 ら ${ }^{23)}$ の線䧿性骨異形成症，松田ら ${ }^{36)}$ の粘液腫または線維性骨

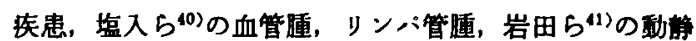

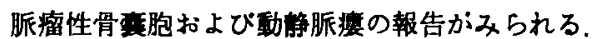

発生機序: Gorlin ら'は顥の血管腫の発生は多分先天 的であろうと述ぺている．Smith") は骨の血管腫は骨内 の血管から生じたもの (一次性)，骨膜の血管から生じ たもの（二次性）があると述ぺており, Armbrecht ら50) (1966) は類の血管隀を文献例39例について A. Central bony hemangioma（この型は骨の骨䯣腔または海綿質

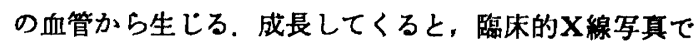
明らかな骨の吸収と顥の皮質の嘻脹が認められる)， B. Peripheral bony hemangioma（この型は骨膜の血管か ら起こり，骨に侵入し，皮質の吸収と網状骨を形成す る）の 2 型に分類することができたと述ぺている，本邦 においても前述したものと同様な考えから，塩入ら 続発性の症例であると，滝川ら ${ }^{17}$ は骨随性のるのと，阿 部ら ${ }^{35)}$ は中心性の症例であると考察している，著者らは 自験例を中心性であると考えている。

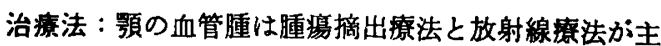
な治療法として述べられているが3，実䏅はさまさまな 治療法が報告されている. Hoey ら6)によれば40例（下

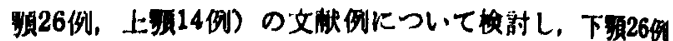

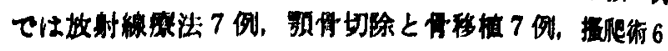

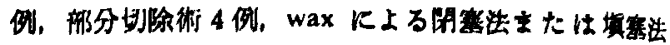

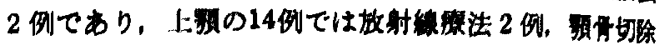

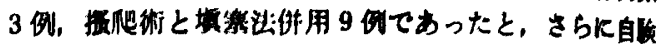

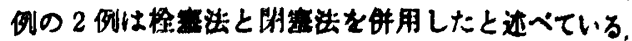

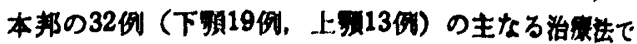

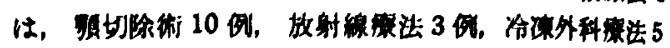

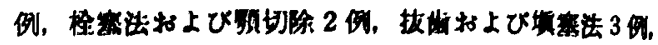

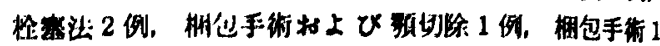

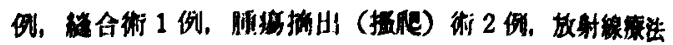

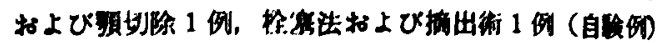
であった（表1）.

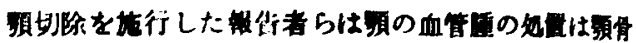

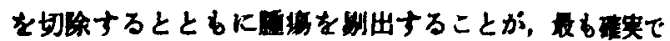

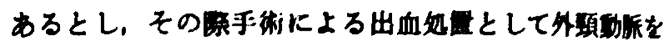

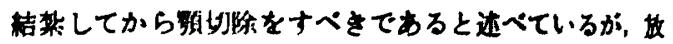

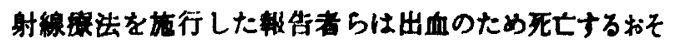
れがあるとして放射線泊無をすナめている。

䫅切除を旗行した場合には，手街中の出血ととるに，

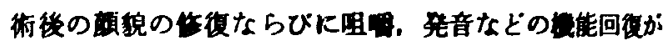

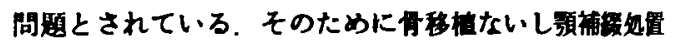
がさており，胜情移植即時再建は Weinstein $5^{46)}$,

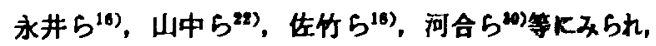
半年後に頻再建はPiercell ら

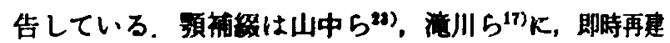
しなかった 例 $24,36,10,53)$ b轱告されている. Davies

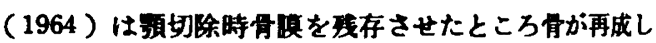
ていたと述べている. 部分切馀街施行者 $5^{5,55)}$ は，摘出

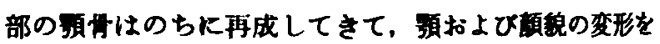
回避することができたと速べている。

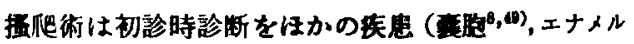

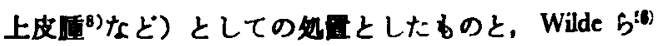
(1966), Mohnac ら 54 (1967) の初めから血管盾に対才 ろ手術としての報告がみられる。

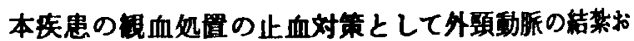

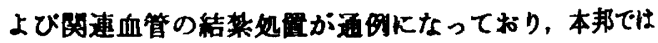
32应例中23例 (約72\%) 下認められている（表1）。

外頊動脈の結热による止血効果について，効果のあっ

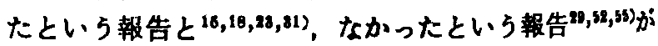
みられる。佐竹ら ${ }^{(6)}$ は他完で斿行された外頊動脈結禁 に，さらに術前の血管撮影によって病巣への策篒血で

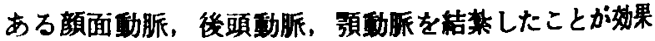
的であったと報告している．塩入ら(0)は外影動脈の各枝

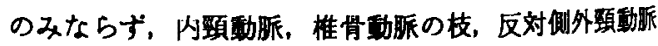
の吻合枝などが関与していたと述ぺている。

以上からして，血管結禁の効果が手術における出血量 に関連していると思われるが，出血量の多い報告は， Davies ${ }^{52}$ の 8 pints (約 $3,485 \mathrm{ml}$ ), Zelesin $ら^{55)}$ の 4,000 
$\mathrm{ml}$, La Daw ら ${ }^{37)}$ の 2,300 ml, Kelley $5^{3)} の ~ 2,200 \mathrm{ml}$ があり，本邦では中島 $5^{29}$ の6, $000 \mathrm{ml}$,塩入ら ${ }^{10)}$ の 2,800 $\mathrm{ml}$, 松田 ${ }^{36)}$ の $2,000 \mathrm{ml}$ 等の報告が公られ，自験例も $3,400 \mathrm{ml}$ とかなり出血が多かった，自験例の出血につ いて検討してみると，次の 3 点が考えられる。すなわ ち，代術前血管撮影にて主要栄街血管が外頊動脈本幹と 注同程度に抬張した顔面動脈と判定し，栓寒法を施行 するも抬張血管のために効果がほとんどなかったこと， (2)顔貌の变形および額機能障害をできるたけ少なくする ため手術視野の㹧い口内法による䫑骨保存撜法を施行し たこと，(3手術中外頸動脈，舌動脈，顔面動脈を結热し たのに，止血效果がほとんどなく，下腹梢動脈絬婪によ り，やっと止血效果が現れたが，それまでの時間が長く かかったことが考えられる。

放射線潦法は Thoma ${ }^{3)}$ により顔面变形を防ぐ方法と して推せんされており，その祭，最少の線量を 3〜4か 月間に絽り返し用射するとしているが，この方法も完全

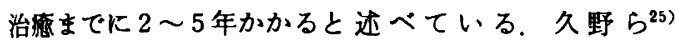

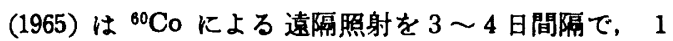
日の照射量を $100 \mathrm{r}$ とし，総量 $1300 \mathrm{r}$ を照射して 8 か月 目に症状が逍退したと報告している，Smith4)，Laws'等 による放射線治療成功例も報告されているか， GamezAraujo 5 ${ }^{58)}$ は放射線治療で腫焬は樎小したが，やがて 增大してきたので顥切除を施行したと，Perriman $5^{59)}$ (1974) 62 例の5ち， 1 例は全く放射線療法に反応せ ず硬化剂（肝油脂肪酸ナトリウム）を注入して治癒した と述へている. Bhoweer ら $5^{60)}$ (1975), Gamez-Araujo $5^{58)}$ は，放射線治療は骨の血管腫や，若年患者の時は考 えるべきではないと述へ，その理由として放射線性毛細 管㧪張症，組織壊死，骨および齿の発育の遅延の続発症 が生じるし，また，放射線照射後肉腫が生じるからと述 ペている，Cannon 5 照射した165症例中 $22 \%$ に癌が発育し，また，これらの 癌は照射後 5 ５0年後に発現してきたと述べている．小 谷ら ${ }^{24)}(1964)$ の症例では約18年間の放射線治療後同部 に腺孺が発現したと述へてている，以上のよらな報告から 放射線治療は究極的に組織の悪性化の危険が大きく，第 一に選択する治療法でないと思われる。

冷凍外科潦法法，1961年 A. Cooper が液体窒素を冷 媒とする倲結手術装置を考案し，脳組織で成功して以 来、ほかの臨床分野に利用されるようになり，良性疾患へ の応用と同時に悪性腫瘍の治療の一手段として用いられ ている，この涷結手術は腫痬が体表，あるいは体表に近 い部分に局在するのが本療法の条件の 1 つで局所治療と して施行すべきであり，現時点では特殊の場合を除き，

観血治療その他の補助手段と考えるべきであるといわれ ている ${ }^{02)}$ ，頻骨血管腫に応用された報告では，Hende-

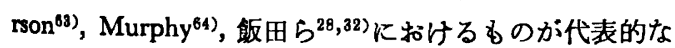
報告と思われる，飯田らによれば中心性血管腫に病巣部

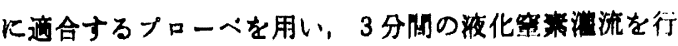

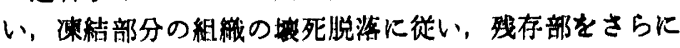
凍絬させていくといら方法で行ったと述へてている：

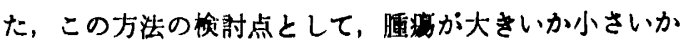
ではなく，深いか浅いかで回数が避らこと，さらに治瘖 期間が長いことが問題で，主幹畍脈の結禁やはかの等法 と併用した方が治療期間を短樎できるのではないかと述 ペている.

硬化绪注入療法は Bhaskar 538)，Chin(s) にみられ sodium morrhuate を洁入して良好な結果であったと述 べている，Bhaskar らは，子供の血管喢は外侮後または 生検後に自然に退行してしまらので程極的治療は推奖で きないと述へ，9歳の症例にこの方法を適用し，䫑骨も 齿牙も保存できたと述へている．Chin は，硬化刘は症 例により単独または外科的切除と併用する療法があり， 副作用として注入剤の疼痛，まれにアレルギー反応およ びフナフィラキシーショックがあると述へている．本邦 では䫏骨血管腫に硬化剂を注入した例 ${ }^{26)} は$ はるか，積極 的治療を行ったといら報告はない。

栓寒法は Lussenhop ら (1960) が脳動脈の治㞠に用 いて以来, 脳以外の血管異常にも用いられるよ5にな り, 顎骨血管腫の治療でも保存療法または手術補助療法 として使われるよらになっだ5) Hoey ら9)，第 1 症 例に腓腹筋片を，第 2 症例に鉛小球と Gelfoam 片を使 用して顎骨内への血管路を明確に閉塞でき，安全に抜歯 できたと報告しており，Lin ら ${ }^{86)}$ は200個の Silicone 小 球を上影の血管腫に，La Dow 5 ${ }^{57)}$ は160個の Silicone 球を下頻の血管尰に用い良好な結果であったと報告して いる. 本邦では古賀ら ${ }^{33)}$, 笠崎ら ${ }^{42)}$ が栓塞法単独療法を, 塩入 ${ }^{40)}$, 桜井 ${ }^{43}$ は顎骨切除のための手術補助療法と して報告されている．栓子として古賀らは Silicone ball 約 90 個, 塩入らは Gelfoam 片100数 10 個, 自験例は Gelfoam片 60個を使用した，腫場の大きな 血管拡張 し た自験例のよらな症例には，栓塞法の効果がなかったけ れども，この点については今後に残された課題として解 明を要するものと思われる.

その他の治療法として拔歯および填塞法が $21,35,39,67,68)$

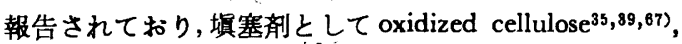

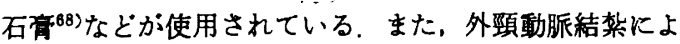
り止血して経過観察している報告 ${ }^{31)}$ ，梱包療法 ${ }^{17,27)}$ がみ られ，Monks ${ }^{69)}$ (1975）は穿刺により治撚した例を報告 している.

病理組紋学的診断：成書にある顎骨血管尰の病理像で は, 欧米と本邦では多少の差異が認められる。 Golin $ら^{1)}$ は一般に䫑骨血管腫は毛細管血管腫と海綿状血管腫 の 2 つの型があり, 大部分の腫瘍は両者の混合型である と記述しており，石川ら²は海綿状血管腫の像をとるの が普通であると記載している．欧米では海綿状血管腫以 外毛細管型血管腫として, Bhaskar $5^{53)}$, Lund $5^{8)}$, 
Gamez-Aramjo $5^{(8)}$, SánchezTorres(1) Piercell $5^{(1)}$,

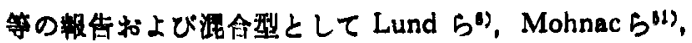
Zalesin ら

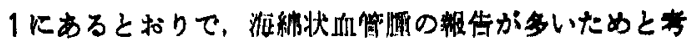
えられる.

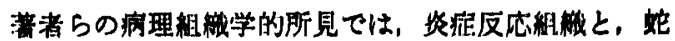

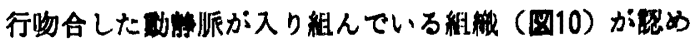

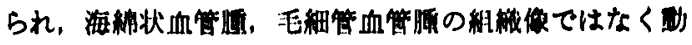

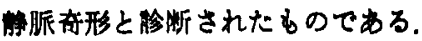

\section{結的}

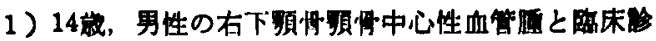
断した症例にカテーテル栓愘法を併用し，口内法にて拉 出術を施行し，影骨を保存することがでをた。

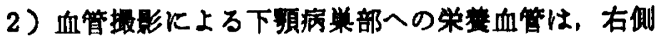

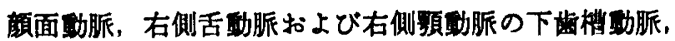

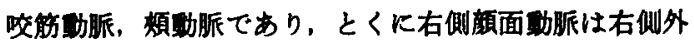
顓動脈本幹とほぼ同程度に払张して䫑骨に進入してい た.

3）顔面勳脈人工栓塞（Gelfoam 小片60個使用）後, 摘出のため, 右側外频動脈本幹, 右側舌動脈, 右側顔面

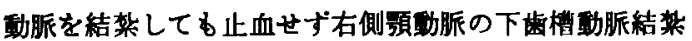
にて止血奻果が現れ摘出することができた。

4) 摘出物の病理組織で初めは異物反応の强い炎症組 織とのことであったが，摘出物標本の全組織切片より， 血管迁ではなく，動静脈奇形之診断された。

5）本邦の文献例32例の，性別，年路，額別発現率， 主訴または主症状および自覚期間，単純X線所見，血管

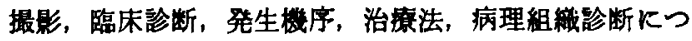
いて検索し，あわせて欧米の報告例とも論じた。

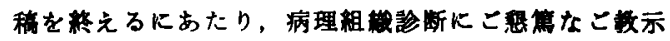
を賜った本学病理の小嶋瑞救授，小形岳三郎数授，島村 香世子博士，木村婎二䍀師, ならびに東京医科畨科大学 石川梧朗名誉救授に束心より感碀を㨂けすす。また，血 管振影に関しこ協力とこ教示を睗った本学放射線科平松

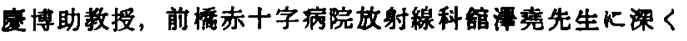
感既を摕けます。

本症例の要旨は，第 124 回日本口腔外科学阙東地方会 （1982年11月13日，神奈川断科大学）に拈いて発表し た。

\section{引用文献}

1) Golin, R. J. and Goldmann, H.M.: Thoma's Oral Pathology. 6 th Ed, Mosby Co, St Louis, 1970, p 564-565.

2) 石川梧朗, 秋吉正豊: 口腔病理学 II. 增補服,

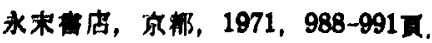

3) Thoma, K.H., Oral Surgery. 5 th Bd, Mosby Co, St Louis, 1969, p 1043-1045.

4) Smith, H.W.: Hemangioma of the jaws. AMA Arch Otolaryngo 70: 579-587 1959.

5) Kelly, D.E., Terry, B.G., et al.: Arteriovenous malformation of the mandible: report of case J Oral Surg 35: 387-393 1977.

6) Hoey, M.F., Courage, G.R., et al.: Management of vascular malformations of the mandible and maxilla: review and report of two cases treated by embolization and surgical obliteration. J Oral Surg 28: 696-706 1970.

7) Laws, I.M.: Pulsating hemangiomata of the jaws. Brit J Oral Surg 5: 223-229 1968.

8) Lund, B.A. and Dahlin, D.C.: Hemangiomas of the mandible and maxilla. J Oral Surg 22: 234-242 1964.

9) Lamberg, M.A., Tasanen, A., et al.: Fatality from central hemangoma of the mandible. J Oral Surg 37: 578-584 1979.

10) Hitzrot, J.M.: Hemangioma cavernosum of bone. Ann Sung 65: 476-482 1916.

11) Bucy, P.C. and Capp, C.S.: Primary hemangioma of bone. Amer J Roentgenol 23: 1331930.

12) Geschickter, C.F. and Maseritz, I.H.: Primary hemangioma involving bone of the extermities. J Bone Joint Surg 20: 888-900 1938.

13) Watson, W.L. and McCarthy, W.D.: Blood and limph vesser tumors. Surg Gynec \& Obst 71: 569-588 1940.

14) Dahlin, D.C.: Bone tumors. 3 rd Ed, Charles C Thomas, Springfield, 1978, p 137-148.

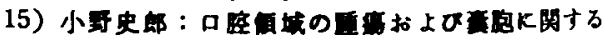

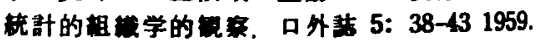

16）永井笠，山中弘之，他：下顽骨中心性血管盾 の 1 何. 242: 21-25 1963.

17）澺川富爑，寺門正昭，他：口空外科犆城のいわ

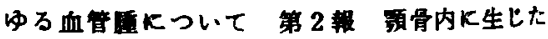
血管盾について。 日大学 44: 658-669 1970.

18）佐竹幸壦，田代英壦，他：下影骨中心性血管盾 の 1 俰. 日只外 21: 170-175 1975.

19）满本员二, 埴田更利，他：最近10年間における

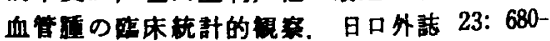
6881977.

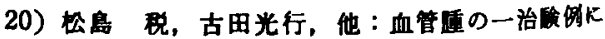

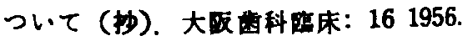

21）河西一秀：上碩骨に発生した血管畽と思われる 一例 (抄)。只科誌 6: 2541957.

22）山中弘之, 淵端孟，他：下颛骨に発生した骨 血管㣫（抄）。科誌 12: 1401963.

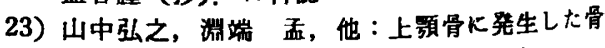
血管腫の1例。口科誌 13: 54-60 1964.

24）小谷朗，金田放郎，他：上颖骨体に海楾状血

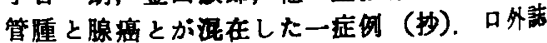


10: 3431964.

25）久野吉雄，高橋秀太郎，他：下影骨に発生した 血管腯の ${ }^{80} \mathrm{Co}$ 炤射による1治䑪例儿ついて。 口外誌 11：240-243 1965.

26）藤井样江，江盛司郎，他：下影骨に生じた血管 腯の 1 症例 (抄). 口科誌 15: 431-432 1966.

27）中久喜 喬, 古川正，他：下頻骨に発生した 血管腫の 1 例（抄)。科学報 67: 450 1967.

28）飯田 武, 天羽 峪, 他：上蒷に発生した中心 性血管腯の冷珠外科法（抄）。只科誌 23 : 2451974.

29）中島泰臣，池尻茂，他：下䂆骨内に原発した と考えられる血管膇の一治敛例 (抄). 口科誌 23: 2531974.

30) 河合幹, 立松 充, 他：下預骨に発生した頻 骨中心性血管䐺の 1 例，日口外誌 22：373-381 1976.

31）山田隆一，小島正明，他：下䝠骨中心性血管尰 の1例. 日外誌 22: 801-804 1976.

32）领田武，松本晃一，他：血管畽に対する Cryosurgery. 日外誌 23: 513-520 1977.

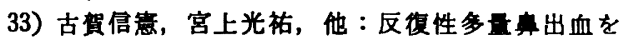
伴 5 上䫑血管属の人工栓塞法による一洽硂例. 耳喉 51: 185-189 1979.

34) 清水正㓮, 水谷 雄, 他：下䫑骨体の動静脈吻 合 (arterio-venous shunt) を伴った血管尰の 1 例（抄). 日外誌 25: 1243-1244 1979.

35）阿部広幸，末石玄一，他：齿肉出血を主訴とし た右㑡上䫑骨血管腫の抜歯経監. 日口外誌 25: 1537-1541 1979.

36）松田 登, 小川 卓, 他：多血球性に生した下 䫑骨中心性血管腫の症例. 日口外誌 26: 126312681980.

37）山下一郎，黒江純一，他：下額骨に発生した血 管尾の一例 (抄)。只科誌 29: 617-618 1980.

38）石川武密, 安井良一, 他: 上額骨体中心性のい わゆる “pulsating haemangioma” の 1 应例に ついて (抄). 日外誌 27: 3101981 .

39）二瓶 徽, 三隅健三, 他 : 上額骨中心性血管連 の1例（抄）. 日外誌 27: 5441981.

40) 塩入重榇, 大西正俊, 他: カテール栓塞法 (CATHETER EMBOLIZATION) の頻骨血 管腫治㾣への底用一一下䫑に主病变を有する巨 大な小児血管隀の 1 治検例一一。口外誌 23: 680-688 1977.

41）岩田康一，金沢美智子, 他 : 下䫓骨中心性血管 腫の1例（抄). 日口外誌 27: 804 1981.

42）笠渏安則, 山下 誠, 他 : 上額に発生した AVM の1例 (抄). 日口外誌 28: 5471982.

43）楼井精人, 田村 稳, 他: カテーテル栓塞法を 底用した下额骨中心性血管腫の一治覧例 (抄). 口科誌 32: 432-433 1983.

44）楖沢策孝, 神田 㓝, 他：下䫓骨に発生した動 静脈袋の 1 例(抄)。 口科誌 32: 827-828 1983.

45) Chin, D.C.: Treatment of maxillary hemangioma with a sclerosing agent. Oral Surg
55: 247-249 1983.

46) Weinstein, I. Yamanaka, H., et al.: Resection and reconstruction of the mandibule for removal of a central hemangioma. Oral Surg 16: 1-13 1963.

47) Worth, H.M. and Stoneman, D.W.: Radiology of vascular abnormalities in and about the jaws. Dent Radiogr Phtogr 52: 1-23 1979.

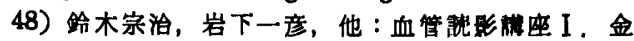
原出版，東京，1972，16-36面。

49) Choukas, N.C., Toto, P.D., et al.: Sclerosing cavernous hemangioma of the maxilla. Oral Surg 16: 17-20 1963.

50) Armbrecht, E.C., Ahmed, M., et al.: Hemangiomas of the maxillofacial region. Oral Surg 22: 286-289 1966.

51) Piercell, M.P., Waite, D.E., et al.: Central hemangioma of the mandible; intraoral resection and reconstruction. J Oral Surg 33: 225-232 1975.

52) Davies, D.: Cavernous hemangioma of the mandible. Plast Recnstr Surg: 457-461 1964.

53) Bhaskar, S.N. and Dubit, J.: Oral surgeryoral pathology conference No. 20, Walter Reed Army Medical Center. Oral Surg 23: 385-390 1967.

54) Mohnac, A.M. and Smith, J.R.: Central heman gioma of the mandible: report of case. J Oral Surg 25: 455-459 1967.

55) Zalesin, H.M., Rotskoff, K., et al.: Central cavernous hemangioma of the mandible treated by an intraoral approach. Oral Surg 33: 877-884 1975.

56) Wilde, N.J., Tur, J.J., et al.: Hemangioma of the mandible: report of case. J Oral Surg 24: 549-552 1966.

57) La Dow, Jr. C.S., Tatoian, Jr. J.A., et al.: Treatment of central hemangioma of the maxilla by embolization: report of case $\mathrm{J}$ Oral Surg 34: 622-626 1976.

58) Gamez-Araujo, J.J., Toth, B.B., et al.: Central hemangioma of the mandible and maxilla. Oral Surg 37: 230-238 1974.

59) Perriman, A., Uthman, A., et al.: Central hemangioma of the jaws. Oral Surg 37: 5025081974.

60) Bhoweer, A.L. and Shirwatkar, L.G.: Central hemangioma of mandible. J Oral Med 30: 111-113 1975.

61) Cannon, B., Randolph, J.G., et al.: Malignant irradiation for benign conditions. New Eng J Med 260: 197-202 1959.

62）中山恒明, 榊原 任監修: 新臨床外科全書. 第 2 巻, 金原出版, 東京, 1979, 463-480頁.

63) Henderson, LTC R.L.: Cryosurgical treatment of hemangiomas. Arch Otolaryng 93: 511- 
5131971.

64) Murphy, J.B.: The management of large hemangioma of the oral cavity with cryotherapy. J Oral Med 33: 104-106 1978.

65) Djindjian, R., Cophignon, J., et al.: Embolization by superselective artheriography from the femoral route in neuroradiology. Review of 60 cases. Neuroradiology 6: 20-26 1973.

66) Lin, S.R., Ladow, Jr. C.S., et al.: Angiographic demonstration and silicone pellet embolization of facial hemangiomas of bone.
Neuroradiology 7: 201-204 1974.

67) Baum, S.M., Pochaczevsky, R., et al.: CenIral hemangioma of the maxilla. J Oral Surg 30: 885-892 1972.

68) SanchezTorres, J, and Vinas, F.: Central mandibular hemangioma. Oral Surg 37: 5095131974.

69) Monks, R.T.: Central angioma of the mandible. A possible treatment. $\mathrm{Br} \mathrm{J}$ Oral Surg 12: 296-297 1975. 